\title{
Evaluation of Healthcare Economics of OECD Countries: Multi-Objective Statistical Optimization
} Model

\section{OECD Ülkelerine ait Sağlık Ekonomilerinin Değerlendirilmesi: Çok Amaçlı İstatistiksel Optimizasyon Modeli}

\author{
Abdulkadir Atalan' ${ }^{1}\left(\right.$, Cem Çağrı Dönmez ${ }^{2}$ (1)
}

${ }^{1}$ (Asst. Prof.), Gaziantep Islam Science and Technology University, Department of Industrial Engineering, Gaziantep, Turkey

${ }^{2}$ (Asst. Prof.), Marmara University, Faculty of Engineering, Industrial Engineering, Istanbul, Turkey

ORCID: A.A. 0000-0003-0924-3685;

C.Ç.D. 0000-0000-0000-0000

\section{Corresponding author:}

Abdulkadir ATALAN

Gaziantep Islam Science and Technology University, Department of Industrial Engineering, Gaziantep, Turkey

E-mail address: abdulkadiratalan@gmail.com

Submitted: 05.12 .2020

Revision Requested: 10.03.2021

Last Revision Received: 10.03.2021

Accepted: 11.03.202

Published Online: 27.04.2021

Citation: Atalan, A., \& Donmez, C.C. (2021). Evaluation of healthcare economics of OECD countries: Multi-objective statistical optimization model. Acta Infologica, 5(1), 197-206. https://doi.org/10.26650/acin.836372

\begin{abstract}
Healthcare systems comprise the most crucial factors affecting countries economically. In this study, the infrastructure and economic structure of healthcare systems belonging to the Organization for Economic Co-operation and Development (OECD) countries are discussed to evaluate the healthcare expenditures (HE) and healthcare expenditures per capita ( $\mathrm{pcHE}$ ) of OECD members. We have identified factors related to healthcare economics and analyzed the significance ratios of these factors to calculate the feasible values of the factors affecting the healthcare systems in the OECD members by statistical optimization analysis. Within the feasible values obtained by using a multi-objective optimization model (MOOM) because of statistical analysis, the HE of OECD countries was minimized, and an improvement of 29.13\% was achieved. The second objective function aimed to maximize the pcHE that was estimated to be at least $\$ 5,282.37$ for the OECD members. Consequently, in countries that do not have a social healthcare system, it is perceived that HE amounts are excessive. The fundamental reason for this situation represents the healthcare sector's perception as a business in those countries.

Keywords: OECD Countries, Healthcare Expenditure, Healthcare Expenditure Per Capita, Multi-Objective Optimization Model, Statistical Analysis
\end{abstract}

ÖZ

Sağlık sistemleri, ülke ekonomilerini etkileyen en önemli faktörlerden birdir. Bu çalışmada, OECD üyelerinin sağlık harcamalarını (SH) ve kişi başına düşen sağlık harcamalarını (kbSH) değerlendirmek için Ekonomik İşbirliği ve Kalkınma Teşkilatı (OECD) ülkelerine ait sağlık sistemlerinin altyapısı ve ekonomik yapısı tartışılmıştır. İstatistiksel optimizasyon analizi ile OECD üyelerindeki sağlık sistemlerini etkileyen faktörlerin uygulanabilir değerlerini hesaplamak için sağlık ekonomisi ile ilgili faktörleri belirlenerek, bu faktörlerin önemlilik oranlarını analiz ettik. İstatistiksel analiz aracılığıyla çok amaçlı optimizasyon modeli (MOOM) kullanılarak elde edilen uygulanabilir değerler içerisinde OECD ülkelerinin SH'si minimize edilmiş ve \% 29,13 oranında iyileşme sağlanmıştır. İkinci amaç fonksiyonu ise OECD üyeleri için kbSH'yi maksimize etmek amaciyla en az kbSH değeri 5.282,37 dolar olarak tahmin edilmiştir. Sonuç olarak sosyal sağlık sistemi olmayan ülkelerde SH miktarlarının aşırı olduğu algılanmaktadır. Bu durumun temel nedeni, sağlık sektörünün o ülkelerdeki bir işletme olarak algılanmaktadır.

Anahtar kelimeler: OECD Ülkeleri, Sağlık Harcamaları, Kişi Başına Düşen Sağlık Harcamaları, Çok Amaçlı Optimizasyon Modeli, İstatistiksel Analiz 


\section{INTRODUCTION}

The OECD aims to develop policies to increase the economic and social well-being of people living in the world (OECD 2017e). The 35-member organization is a platform for cooperation between governments to seek solutions to common problems (OECD 2017d). The most critical issue among the issues of these countries is the healthcare-related challenge (Atalan 2018). In today's world, the importance of the healthcare field is increasing. The main reason for this is that people want to live in more developed economies. This shows that the economic development and progress in healthcare are directly proportional. OECD countries have spent about \$6.02 trillion in healthcare expenditures in 2017 (Atalan 2020).

Several studies have been conducted on the healthcare systems of OECD members. Relations between healthcare economics and economic dimensions of the countries have been sought in these studies. In 1992, a study of 19 OECD countries covered the aggregate gross domestic product (GDP) and socio-demographic factors affecting HE (Gerdtham et al. 1992). The OECD countries' PC and GDP data have been used to obtain unit root test results due to time series. In this study, the method used was a panel of OECD data (McCoskey and Selden 1998). In the panel data models, the correlation was developed in which the factors affecting the model are specified in the time-series dimension (Albouy, Davezies, and Debrand 2010). Another study directly examined the long-term economic relationship between HE and GDP as a panel data of the 20 members of OECD for the period 1971-2004 (Baltagi and Moscone 2010).

Using data from OECD countries, some studies have been carried out on the performance that showed the healthcare quality of those countries (Arah et al. 2006). Surveys or verbal dimensions examined in most of these studies were done without using any quality tools. However, to obtain quantitative and tangible findings in healthcare economics, some statistical and engineering techniques were applied in the mentioned studies related to healthcare costs. In particular, generalized linear models were used as the conventional method for reducing the skewness of the data (Malehi, Pourmotahari, and Angali 2015). Furthermore, regression methods were used to find the relationship between the factors and the response variables related to healthcare systems (Carides, Heyse, and Iglewicz 2000; Gregori et al. 2011; Jones, Lomas, and Rice 2015; Mihaylova et al. 2011). This study's goas was to determine the factors affecting healthcare economics and calculate these factors' optimum values using a statistical optimization approach.

Another method used in health studies was the optimization technique (Atalan 2019). Optimization techniques are the required methods used in management, engineering, and business applications. The purpose of using optimization or operation research techniques is to provide maximum benefits (such as revenue, production, etc.) and minimize loss (such as costs, waiting time, etc.). Optimization applications have been widely used in energy, automotive, manufacturing, transportation, and healthcare. It is common for optimization models related to waiting times to be applied in the healthcare field (Atalan and Donmez 2019). Likewise, in other health care issues, for example, the number of patients treated in hospitals, length of hospital stays, hospital resources utilization rates, etc. optimixation methods have been tried to solve these areas of concern (Ajami, Ketabi, and MahmoodAbadi 2013; Iii, Hwang, and Nagarajan 2001).

Generally, there is one objective function in optimization models for applications. A model is created by creating a single objective function in MOOM and transforming the remaining objective functions into constraints (Ngatchou, Zarei, and El-Sharkawi 2005). For this reason, developed optimization models are not tempting to use the single-objective function of optimization models for such problems. Among the most important elements that complicate problems are the multi-objective functions (Mason, Duggan, and Howley 2017). It is inevitable to use MOOM to overcome economic complexity. The application of MOOM has not been addressed much in the field of healthcare. MOOM has been used to increase the population homogeneity and diversity of the small regions' medical services and minimize the distance between the micro-regions visited by patients (Steiner et al. 2015). In this study, two objective functions were formulated with the economic aspects of the healthcare systems of OECD members. The first objective function was to maximize the amount of pcHE in OECD countries (Atalan 2018). Secondly, attention was paid to minimizing the HE of OECD members.

In the research carried out so far, healthcare economics factors are considered to be demographic or social justice in nature (Dukhanin et al. 2018). However, the fact that the factors are quantitative and correct according to their values provides 
convenience in statistical analysis. During the economic crisis in Europe in 2010, the healthcare systems belonging to European countries were affected (Atalan, Cinar, and Cinar 2020). European governments tended to reduce health expenditures during the crisis, but in some countries, which did not provide healthcare insurance policies, healthcare pocket payments increased. In support of this action, we advocate that healthcare economics should not be affected by the economic fluctuations of countries. Moreover, it has been stated that healthcare expenditures are increased by reducing the number of healthcare workers and hospitals in the healthcare systems in the time of economic crisis (Palasca and Jaba 2015).

This study examined the healthcare infrastructure of OECD members and applied the multi-objective statistical optimization method needed in order to have a better healthcare system. The five input variables (or factors) and two output variables (defined as objective functions of the multi-objective optimization model) that affect healthcare systems were expressed for this study. There were two stages of statistics and mathematical programming used in the present study. First, the variables of the healthcare system were statistically analyzed and then included in the optimization process. The reason for using MOOM in this study is that there are pcHE and HE variables defined as two different objective functions. The optimum values of decision variables and objective functions were calculated for OECD members to have a better healthcare system.

The present study consists of four sections. A literature review explaining about healthcare systems and healthcare economics is in the first section. The second part includes the factors affecting the healthcare systems of OECD members that form the methodology of this study. The results of the numeric example are considered in the third section. The conclusion of the study is discussed in the last section.

\section{METHODOLOGY}

\subsection{Defining Variables of Independent and Responses}

In terms of economy, many factors are influential in the healthcare system level headedly. Before determining the factors of healthcare economics, it is necessary to examine healthcare systems worldwide. There are two types of healthcare systems worldwide: private and state healthcare systems (Liu et al. 2018). Social countries have more health expenditures than nonsocial countries (Muyl, Dumas, and Herbert 2004). However, private healthcare systems have developed in non-social states such as the U.S. healthcare system. This is because most of the HE is covered by patients or those with health insurance in these countries.

This part of the research contains information on the data and methods to be used for healthcare economics. The healthcare economics of OECD members along with seven fundamentals: gross domestic product (GDP), gross domestic product per capita (pcGDP), life expectancy (LE), the total numbers of healthcare employments (E) of a member of OECD, and pharmaceutical expenditure (PE) were defined as a factor or independent variables and healthcare expenditure (HE) and healthcare expenditure per capita (pcHE) were assigned as a response or dependent variables in this study. The statistics optimization analysis calculates the significance ratings and feasible values of these factors. The responses and factor variables are examined one by one in Table 1. 
Table 1

Indicators of OECD's healthcare systems

\begin{tabular}{|c|c|c|c|}
\hline Variables & Status & Notations & Description \\
\hline Healthcare Expenditure & $\begin{array}{l}\text { Response } \\
\text { (Output) } \\
\text { Variable }\end{array}$ & $\mathrm{y}_{\mathrm{h}}$ & $\begin{array}{l}\text { HE (\% of GDP) of OECD countries was considered (Bichay 2020; OECD 2016a). The } \\
\text { general belief, as people's quality of life and their willingness to live increases, HE also } \\
\text { increases. The optimization model is provided to minimize the amount of HE, which is } \\
\text { the objective function. }\end{array}$ \\
\hline $\begin{array}{l}\text { Healthcare Expenditure } \\
\text { Per Capita }\end{array}$ & $\begin{array}{l}\text { Response } \\
\text { (Output) } \\
\text { Variable }\end{array}$ & $\mathrm{y}_{\mathrm{pc}}$ & $\begin{array}{l}\text { The second response, which is influenced by the factors considered, is the pcHE (OECD } \\
\text { 2016b). The second optimization model stated that the pcHE should be maximum, and the } \\
\text { feasible values of the factors constituting the constraints should be in this study. }\end{array}$ \\
\hline Gross Domestic Product & $\begin{array}{l}\text { Factor (Input) } \\
\text { Variable }\end{array}$ & $\mathrm{x}_{\mathrm{g}}$ & $\begin{array}{l}\text { The GDP factor is assumed to affect an economy on HE and pcHE (WBG 2017). Countries } \\
\text { with large GDP ratios can be thought of as determining the proportion of their budget for } \\
\text { their healthcare systems. }\end{array}$ \\
\hline $\begin{array}{l}\text { Gross Domestic Product } \\
\text { Per Capita }\end{array}$ & $\begin{array}{l}\text { Factor (Input) } \\
\text { Variable }\end{array}$ & $\mathrm{x}_{\mathrm{pc}}$ & $\begin{array}{l}\text { Among the factors that can affect healthcare economics, it is considered the pcGDP factor } \\
\text { (WBG 2017). }\end{array}$ \\
\hline $\begin{array}{l}\text { Pharmaceutical } \\
\text { Expenditures }\end{array}$ & $\begin{array}{l}\text { Factor (Input) } \\
\text { Variable }\end{array}$ & $\mathrm{x}_{\mathrm{p}}$ & $\begin{array}{l}\text { PE is thought to be particularly effective in HE (OECD 2017c). The average of OECD } \\
\text { countries' PE is } 1.4 \% \text { of GDP. }\end{array}$ \\
\hline Life Expectancy & $\begin{array}{l}\text { Factor (Input) } \\
\text { Variable }\end{array}$ & $\mathrm{x}_{1}$ & $\begin{array}{l}\text { LE data of OECD countries have been taken into consideration (OECD 2017a). The } \\
\text { average LE is } 80 / 65 \text { in OECD countries (C. and B. 1977). }\end{array}$ \\
\hline $\begin{array}{l}\text { Total number of Health } \\
\text { and Social Employment }\end{array}$ & $\begin{array}{l}\text { Factor (Input) } \\
\text { Variable }\end{array}$ & $\mathrm{x}_{\mathrm{e}}$ & $\begin{array}{l}\text { Total Health and Social Employment of countries are considered in OECD members } \\
\text { (OECD 2017b). }\end{array}$ \\
\hline
\end{tabular}

The method used in this study is an improved linear regression equation with multiple independent variables. The healthcare economies involved are expressed by the following general eq. 1 to measure the contribution of the HE and pcHE for OECD countries.

$$
\mathrm{y}_{\mathrm{i}}=\beta_{0}+\beta_{\mathrm{i}} \mathrm{x}^{\mathrm{ij}}+\epsilon_{\mathrm{i}}
$$

where; the value of $y_{i}$ represents the response value, the constant values estimate the parameters $\beta_{0}$, the fitted values estimate the parameters $\beta_{\mathrm{i}}$, the parameter $\mathrm{x}_{\mathrm{ij}}$ describes the factors, $\mathrm{i}=\{$ defined independent or input variables $\}$ and $\mathrm{j}=\{$ countries or OECD members $\}$.

\subsection{Multi-Objective Optimization Models (MOOM)}

The MOOM is often used with common constraints and applied to find the best balance between two different objective functions (To be minimized or maximized). Mathematical explanations (a general formulation) of MOOM are as follows (Deb and Kalyanmoy 2001);

$$
\begin{aligned}
& \text { Min or } \operatorname{Max}_{j}(x), j=1,2, \ldots, J \\
& g_{a}(x) \geq 0, a=1,2, \ldots, A \\
& h_{b}(x)=0, k=1,2, \ldots, B \\
& x_{i}^{(L)} \leq x_{i}^{(U)}, i=1,2, \ldots, n
\end{aligned}
$$

where; $\mathrm{L}$ represents the lower bound, and $\mathrm{U}$ expresses the upper bound. In single-objective optimization models, the superiority ratios of a solution are compared to those of other solutions. That is, the values of the target function can be easily reached. However, in a multi-objective optimization problem, a solution is feasible determined by dominance. This optimization model is used to produce the Pareto boundary of the two objective functions most effectively. The feasible solution range is created by expressing the nonlinear line in which the max-max, min-min, or max-min in the Pareto graph is best described.

There are two different responses at the center of healthcare economics by examining the data in the study. In the mathematical optimization models created, there are two objective functions. For this reason, a MOOM was applied in this study. These objective functions are to maximize the HE and minimize the pcHE. The same constraints of factors are used for both objective functions. 
As a result of the regression analysis, there are some constraints related to the derived objective functions. These constraints are composed of the factors affecting healthcare economics, and these factors have upper and lower limits (see equations 5 , 6, and 7). The generated optimization models (see equations 3 and 4) are expressed as follows:

$$
\begin{array}{ll}
\operatorname{Maximize}_{\mathrm{yh}} & \beta_{0}+\beta_{1} \mathrm{x}_{\mathrm{gj}}+\beta_{2} \mathrm{x}_{\mathrm{pcj}}+\beta_{3} \mathrm{x}_{\mathrm{lj}}+\beta_{4} \mathrm{x}_{\mathrm{pj}}+\beta_{5} \mathrm{x}_{\mathrm{ej}}+\epsilon_{\mathrm{i}} \\
\text { Minimize }_{\mathrm{ypc}} & \beta_{0}+\beta_{1} \mathrm{x}_{\mathrm{gj}}+\beta_{2} \mathrm{x}_{\mathrm{pcj}}+\beta_{3} \mathrm{x}_{\mathrm{lj}}+\beta_{4} \mathrm{x}_{\mathrm{pj}}+\beta_{5} \mathrm{x}_{\mathrm{ej}}+\epsilon
\end{array}
$$

subject to

$$
\begin{aligned}
& 1 \leq x_{i j} \\
& u \geq x_{i j} \\
& 0 \leq x_{i j}
\end{aligned}
$$

\section{RESULTS AND DISCUSSIONS}

The correlation of the data used with each other was examined in Table 2. The correlation values demonstrate factors that strongly correlate with which factor or which responses. The results obtained from the correlation calculations need to have

\begin{tabular}{|c|c|c|c|c|c|c|}
\hline Variables & $\mathbf{x}_{g}$ & $\mathbf{X}_{\mathrm{pc}}$ & $\mathrm{x}_{1}$ & $\mathbf{x}_{\mathrm{e}}$ & $x_{p}$ & $y_{p c}$ \\
\hline$x_{p c}$ & 0.162 & & & & & \\
\hline$x_{1}$ & -0.023 & 0.598 & & & & \\
\hline$x_{e}$ & 0.793 & 0.089 & 0.103 & & & \\
\hline$x_{p}$ & 0.376 & -0.408 & -0.252 & 0.365 & & \\
\hline$y_{p c}$ & 0.528 & 0.883 & 0.500 & 0.376 & -0.120 & \\
\hline$y_{h}$ & 0.681 & 0.480 & 0.431 & 0.540 & 0.244 & 0.794 \\
\hline
\end{tabular}
a value between -1.00 and 1.00 - the closer to 0 , the less correlated between the data. However, if the value obtained is close to 1.00 or -1.00 , it is understood that there is a strong relationship between the data.

Table 2

Correlation relationship among variables

The effect of data used in this analysis on the response was measured. The primary purpose of using this analysis was to determine which regression analysis was appropriate for the data used. Thirty-five countries are members of the OECD, i.e., fitted regression analysis was required to measure the data from five different factors and two response variables with appropriate analysis. The statistical analysis accuracy was $72.16 \%$ of the $\mathrm{R}^{2}$ value and $67.36 \%$ of the adjusted $\mathrm{R}^{2}$ value for

\begin{tabular}{|c|c|c|c|c|}
\hline \multirow{2}{*}{ Factors } & \multicolumn{2}{|r|}{ HE } & \multicolumn{2}{|r|}{ pcHE } \\
\hline & Probability & Status & Probability & Status \\
\hline $\mathrm{x}_{\mathrm{g}}$ & 0.001 & Significant $<0.05$ & 0.002 & Significant $<0.05$ \\
\hline $\mathrm{x}_{\mathrm{pc}}$ & 0.071 & Provisional Significant $<0.05$ & 0.005 & Significant $<0.01$ \\
\hline $\mathrm{x}_{1}$ & 0.010 & Significant $<0.05$ & 0.566 & Insignificant $<0.1$ \\
\hline $\mathrm{x}_{\mathrm{e}}$ & 0.444 & Insignificant $<0.1$ & 0.052 & Insignificant $<0.1$ \\
\hline$x_{p}$ & 0.057 & Significant $<0.05$ & 0.079 & Provisional Significant $<0.1$ \\
\hline
\end{tabular}
$\mathrm{HE}$ and $93.95 \%$ of the $\mathrm{R}^{2}$ value and $92.90 \%$ of the adjusted $\mathrm{R}^{2}$ value for pcHE. The results obtained by the regression analysis were rated as necessary (see Table 3).

Table 3

Analysis of variance of regression analysis for $\mathrm{HE}$ and $\mathrm{pcHE}$

The effect of 3 out of 5 factors were compared to the others on the response variable HE. In short, LE and E factors were less affected by HE. Especially the effect of the GDP (M) and pcGDP factors of the OECD countries on the healthcare economy seemed to be excessive. Another factor influencing healthcare economics was the amount of expenditure for the pharmaceutical sector. In the regression analysis, except for the factors used for HE, except LE, the others affected the HE 
variable. E was added to the model even though the effect is small. Although the p-value of PE is close to 0.05 , the value of the model's impact is 49225 . Besides, as the factors are handled one by one, their interaction needs to be considered. In particular, the interaction of the factors GDP and $\mathrm{E}$ has been shown to affect response (p-value is 0.013 ) significantly. Likewise, the value of the interaction of the factors GDP and PE is close to 0.05 , which is embedded in the model. However, the interaction of the pcGDP factor itself with the regression equation's nonlinear model has been removed from the model due to its weakness ( $\mathrm{p}$-value is 0.071 ; we can accept this factor as conditional).

According to the statistical analysis, pcHE was defined as a second objective function, GDP, and pcGDP factors have a significant effect on the response variable. The $\mathrm{E}$ factor impact on $\mathrm{pcHE}$ is based on substantial evidence, but it is accepted that if the significance level ratio is close to 0.05 . PE has a significant effect, even if it has weak evidence. Negatively, the LE factor has not counted any effect on the response variable. The regression coefficients of all factors except factor $\mathrm{E}$ have a positive value. The constant number, called the regression coefficient (known as the constant coefficient that gives the regression slope), has a negative value, which is -0.233 .

The two regression equations obtained at the same time constitute the objective functions of this study. The first objective function was evaluated for HE (see equation 8). The second regression equation (defined as the second-objective function) belongs to pcHE (see equation 9). The equations were defined as follows:

$$
\begin{aligned}
& \text { Maximize }_{\mathrm{yh}}\left[-2363+0.000250 * \mathrm{x}_{\mathrm{gj}}+0.07974 * \mathrm{x}_{\mathrm{pcj}}+30.1 * \mathrm{x}_{\mathrm{lj}}-0.000024 * \mathrm{x}_{\mathrm{ej}}+49225 * \mathrm{x}_{\mathrm{pj}}\right] \\
& \text { Minimize }_{\mathrm{ypc}}\left[-0.233+0.000012 * \mathrm{x}_{\mathrm{gj}}+0.000010 * \mathrm{x}_{\mathrm{pcj}}+0.00358 * \mathrm{x}_{\mathrm{lj}}-0.00001 * \mathrm{x}_{\mathrm{ej}}+1.334 * \mathrm{x}_{\mathrm{pj}}\right] \\
& \mathrm{x}_{\mathrm{ij}} \geq 0.00 ; \mathrm{i}=\{\mathrm{g}, \mathrm{pc}, 1, \mathrm{e}, \mathrm{p}\}, \mathrm{j}=\{\text { OECD members }\}
\end{aligned}
$$

The same constraints were used for the objective functions (see equations Table 4). A limit was established by calculating the maximum (upper limit) and minimum (lower limit) values of the results of these constraints. Finally, these factors that make up decision variables that need to be greater than zero (see equation 10).

\begin{tabular}{|c|c|c|}
\hline Variables & Lower Limits & Upper Limits \\
\hline$x_{g j}$ & $\$ 17,180.0$ & $\$ 18,624,475.00$ \\
\hline $\mathrm{x}_{\mathrm{pcj}}$ & $\$ 8,209.00$ & $\$ 100,573.00$ \\
\hline $\mathrm{x}_{\mathrm{lj}}$ & 74.60 & 83.90 \\
\hline$x_{e j}$ & $5.00\left(\%\right.$ of GDP $\left.\mathrm{j}_{\mathrm{j}}\right)$ & $22.00(\%$ of GDP $\mathrm{j})$ \\
\hline $\mathrm{x}_{\mathrm{pi}}$ & 20944 & 20076000 \\
\hline
\end{tabular}

Table 4

The constraints of the objective functions

The values to be taken by the factors must satisfy the objective functions. The most crucial factor to be considered for this is the desirability values of the objective functions. The desirability value ranges from 0 to 1 . In this study, the desirability value obtained to satisfy both objective functions are 0.5552 . This value is the average of the desirability values of the objective functions. The values show the data required for an OECD country to have a quality structure in the healthcare economy in Table 5. Countries with OECD members must have a minimum GDP of $\$ 1,737,253,440.00$ and a pcGDP of approximately $\$ 54,000.00$. Among findings, members of OECD with these values were also required to reduce pharmacy spending.

Table 5

Feasible values of objective functions and factors

\begin{tabular}{lcccc}
\hline Definitions & Status & Variables & Desirability & Feasible Values \\
\hline & Constraints 1 & $\mathrm{x}_{\mathrm{gj}}$ & - & $\$ 1,737,253,440$ \\
\cline { 2 - 5 } Decision Variables & Constraints 2 & $\mathrm{x}_{\mathrm{pcj}}$ & - & $\$ 53,970.24$ \\
\cline { 2 - 5 } or Input Factors & Constraints 3 & $\mathrm{x}_{\mathrm{lj}}$ & - & 79.46 \\
\cline { 2 - 5 } & Constraints 4 & $\mathrm{x}_{\mathrm{ej}}$ & - & $306207.90 \sim 306208$ \\
\cline { 2 - 5 } & Constraints 5 & $\mathrm{x}_{\mathrm{pj}}$ & - & $1.190 \%$ \\
\hline Maximize & Objective Functions 1 & $\mathrm{y}_{\mathrm{pc}}$ & 0.4768 & $\$ 5,282.38$ \\
\hline Minimize & Objective Functions 2 & $\mathrm{y}_{\mathrm{h}}$ & 0.6394 & $8.970 \%$ \\
\hline
\end{tabular}


The OECD members must set a budget of at least $\$ 5,282.38$ to maximize the pcHE value. The objective function of HE, which is required to be drawn to the minimum level, requires members of OECD to allocate approximately $9.00 \%$ of their GDP budget. For possible values for both objective functions and constraints, the feasible HE of OECD member countries for healthcare have been recalculated with the new method. Under this calculation, some countries spend unnecessarily excessive expenditures. Some countries have found that the percentage of HE in the amount of GDP they have is required to be increased. Seventeen out of 35 OECD member countries spend more on HE. The HE amounts in the U.S. are unusually excessive. Approximately $47.89 \%$ of the HE amounts are seen to pay more. Turkey is experiencing just the opposite in this case. Turkey appears to be insufficient, and it was found that HE should increase at least $107.16 \%$ (It is necessary to spend as much as the current HE).

The feasible HE PC value deducted by the new method developed is calculated as $\$ 5,282.38$ (threshold) on average. It is recommended that pcHE values be maintained or increased in countries (France, Ireland, Luxembourg, Netherlands, Norway, Sweden, Switzerland, and the U.S.) where HE PC values are above feasible. Because HE PC is the best measure of the quality of the health system. According to computational results, 27 out of the 35 OECD countries need to increase the pcHE amount significantly. Otherwise, they will not have a good health system in the future. Especially in two countries, Mexico and Turkey are required to provide an increase of approximately $\$ 4,000.00$.

The resulting feasible values and an improvement in the health economics of OECD countries have been achieved with this study. The budget allocated by members of the OECD for healthcare services is approximately $\$ 6.02$ trillion. The total amount that OECD members will spend on the healthcare sector is about $\$ 4.3$ trillion within the feasible results obtained with this developed application. Within the scope of the targeted values in health economics, HE has been minimized, and an improvement of approximately $29.13 \%$ has been achieved. This improvement will result in wasted expenditure on other investments in the healthcare field. The most crucial incentive factor for this situation is an overpayment in the pharmaceutical sector. The workplace created for the pharmaceutical industry causes people to turn from healthcare services to economic competition in developed and developing countries. The most active component in healthcare systems is the governments at the center of healthcare systems as a rule-maker in healthcare (Atalan and Donmez 2019). For this reason, governments should not allow the pharmaceutical industry to put people's lives at risk.

The second indicator of the healthcare economy is the pcHE. An increase in the amount of pcHE in world countries is requested. The main reason for this is that people want to live under health insurance. The size of the pcHE amount also indicates the quality of the healthcare systems that the countries have. It shows that countries with high HE PC amounts have an advanced healthcare system (technology, quality, adequate resources, etc.). With this method developed, the amount of pcHE in countries should be over $\$ 5,000.00$. It is a known fact that people in countries that do not have a social healthcare system spend too much money on treatment. For this reason, people want to get quality healthcare services if they have certain state or public healthcare insurance (the amount paid or the amount cut off by the government for the insurance premium). However, to provide quality healthcare, members of the OECD need to have the feasible values obtained.

\section{CONCLUSIONS AND FUTURE PERSPECTIVES}

Healthcare systems are one of the main elements that constitute countries' infrastructures, although the healthcare systems have a complex structure. The healthcare sector is among the largest sectors after the manufacturing industry in the world. In countries with economic developments, it is not surprising that developed healthcare systems exist. The fact that people have a high financial advantage in healthcare has opened the way to get quality healthcare services. There will inevitably be large investments economically to create quality healthcare services. However, to achieve this desired situation, the healthcare economy needs to be appropriately managed.

This study's central theme was to determine feasible results by selecting the effects of the factors that may be effective in healthcare economics on $\mathrm{HE}$ and pcHE. To manage healthcare economics, governments need to use the budgets they allocate efficiently. Consequently, in countries that do not have a social healthcare system, the HE is excessive. The main reason for this situation is the perception of the health sector as a business. With this study, approximately $29.13 \%$ improvement was 
achieved in HE, thereby eliminating waste that occupies the healthcare budget. The other goal of this study was to ensure that the pcHE amount is high in countries that are members of OCED. On average, the pcHE amount was $\$ 4,002.68$. However, it was determined that the pcHE amount of OECD countries should be over $\$ 5,200.00$ with this advanced method. Thus, we have underlined that the quality and infrastructure of healthcare should be improved in these countries.

The applicability of optimization models with statistical analysis has been shown by contributing to the literature with this study. Additionally, this study emphasizes how to solve MOOM as opposed to single-objective optimization models. Researchers generally think that MOOMs are difficult to solve, and they come up with a solution by converting optimization models with multiple objective functions into a single objective function. As the future scope of this study, it is proposed to integrate statistical analysis with optimization models to find the optimal economic and social parameters for countries, cities, or institutions.

Hakem Değerlendirmesi: Dış bağımsız.

Çıkar Çatıșması: Yazarlar çıkar çatıșması bildirmemiștir.

Finansal Destek: Yazarlar bu çalışma için finansal destek almadığını beyan etmiştir.

Yazar Katkıları: Çalışma Konsepti/Tasarım- A.K.A., C.Ç.D.; Veri Toplama- A.K.A.; Veri Analizi/Yorumlama- A.K.A.; Yazı Taslağı- A.K.A., C.Ç.D.; İçeriğin Eleştirel İncelemesiA.K.A., C.Ç.D.; Son Onay ve Sorumluluk- A.K.A., C.Ç.D.

Peer-review: Externally peer-reviewed.

Conflict of Interest: The authors have no conflict of interest to declare.

Grant Support: The authors declared that this study has received no financial support.

Author Contributions: Conception/Design of Study- A.K.A., C.Ç.D.; Data Acquisition- A.K.A.; Data Analysis/Interpretation- A.K.A.; Drafting Manuscript- A.K.A., C.Ç.D.; Critical Revision of Manuscript- A.K.A., C.Ç.D.;Final Approval and Accountability- A.K.A., C.Ç.D.

\section{Kaynaklar/References}

Ajami, S., Ketabi, S., \& MahmoodAbadi, H. B. (2013). Reducing Waiting Time in Emergency Department at Ayatollah-Kashani Hospital Using Simulation. Journal of Health Administration, 16(51), 84-94.

Albouy, V., Davezies, L., \& Debrand, T. (2010). Health expenditure models: A comparison using panel data. Economic Modelling, 27(4), 791-803. https://doi.org/https://doi.org/10.1016/j.econmod.2010.02.006

Arah, O. A., Westert, G. P., Hurst, J., \& Klazinga, N. S. (2006). A conceptual framework for the OECD Health Care Quality Indicators Project. International Journal for Quality in Health Care, 18 (supply 1), 5-13.

Atalan, A. (2018). Türkiye Sağlık Ekonomisi için İstatistiksel Çok Amaçlı Optimizasyon Modelinin Uygulanması. İşletme Ekonomi ve Yönetim Araştırmaları Dergisi, 1(1), 34-51. http://dergipark.gov.tr/download/article-file/414076

Atalan, A. (2019). THE IMPACTS OF HEALTHCARE RESOURCES ON SERVICES OF EMERGENCY DEPARTMENT: DISCRETE EVENT SIMULATION WITH BOX-BEHNKEN DESIGN. PONTE International Scientific Researchs Journal, 75(6), 12-23. https://doi.org/10.21506/j.ponte.2019.6.10

Atalan, A. (2020). Forecasting for Healthcare Expenditure of Turkey Covering the Years of 2018-2050. Gümüşhane Üniversitesi Sağllk Bilimleri Dergisi, 9(1), 8-16. https://doi.org/10.37989/gumussagbil.538111

Atalan, A., Cinar, Z., \& Cinar, M. (2020). A TRENDLINE ANALYSIS FOR HEALTHCARE EXPENDITURE PER CAPITA OF OECD MEMBERS. Sigma Journal Of Engineering And Natural Sciences, 10(3), 23-35.

Atalan, A., \& Donmez, C. (2019). Employment of Emergency Advanced Nurses of Turkey: A Discrete-Event Simulation Application. Processes, 7(1), 48. https://doi.org/10.3390/pr7010048

Baltagi, B. H., \& Moscone, F. (2010). Health care expenditure and income in the OECD reconsidered: Evidence from panel data. Economic Modelling, 27(4), 804-811. https://doi.org/https://doi.org/10.1016/j.econmod.2009.12.001

Bichay, N. (2020). Health insurance as a state institution: The effect of single-payer insurance on expenditures in OECD countries. Social Science \& Medicine, 113454. https://doi.org/10.1016/j.socscimed.2020.113454

C., W. M., \& B., S. W. (1977). Foundations of Cost-Effectiveness Analysis for Health and Medical Practices. New England Journal of Medicine, 296(13), 716-721. https://doi.org/10.1056/NEJM197703312961304

Carides, G. W., Heyse, J. F., \& Iglewicz, B. (2000). A regression-based method for estimating mean treatment cost in the presence of right-censoring. Biostatistics, 1(3), 299-313. https://doi.org/10.1093/biostatistics/1.3.299

Deb, K., \& Kalyanmoy, D. (2001). Multi-Objective Optimization Using Evolutionary Algorithms. John Wiley \&amp; Sons, Inc.

Dukhanin, V., Searle, A., Zwerling, A., Dowdy, D. W., Taylor, H. A., \& Merritt, M. W. (2018). Integrating social justice concerns into economic evaluation for healthcare and public health: A systematic review. Social Science and Medicine, 198, 27-35. https://doi.org/10.1016/j.socscimed.2017.12.012

Gerdtham, U. G., Søgaard, J., Andersson, F., \& Jönsson, B. (1992). An econometric analysis of health care expenditure: A cross-section study of the OECD countries. Journal of Health Economics, 11(1), 63-84. https://doi.org/https://doi.org/10.1016/0167-6296(92)90025-V 
Gregori, D., Petrinco, M., Bo, S., Desideri, A., Merletti, F., \& Pagano, E. (2011). Regression models for analyzing costs and their determinants in health care: an introductory review. International Journal for Quality in Health Care, 23(3), 331-341. https://oi.org/10.1093/intqhe/mzr010

Iii, J. H. E., Hwang, Y., \& Nagarajan, N. J. (2001). Management control and hospital cost reduction: additional evidence. Journal of Accounting and Public Polic, 20(1), 73-88.

Jones, A. M., Lomas, J., \& Rice, N. (2015). Healthcare Cost Regressions: Going Beyond the Mean to Estimate the Full Distribution. Health Economics, 24(9), 1192-1212. https://doi.org/10.1002/hec.3178

Liu, Y., Lei, H., Zhang, D., \& Wu, Z. (2018). Robust optimization for relief logistics planning under uncertainties in demand and transportation time. Applied Mathematical Modelling, 55(Supplement C), 262-280. https://doi.org/https://doi.org/10.1016/j.apm.2017.10.041

Malehi, A. S., Pourmotahari, F., \& Angali, K. A. (2015). Statistical models for the analysis of skewed healthcare cost data: a simulation study. Health Economics Review, 5, 11. https://doi.org/10.1186/s13561-015-0045-7

Mason, K., Duggan, J., \& Howley, E. (2017). Multi-objective dynamic economic emission dispatch using particle swarm optimisation variants. Neurocomputing, 270(Supplement C), 188-197. https://doi.org/https://doi.org/10.1016/j.neucom.2017.03.086

McCoskey, S. K., \& Selden, T. M. (1998). Health care expenditures and GDP: panel data unit root test results. Journal of Health Economics, 17(3), 369-376. https://doi.org/https://doi.org/10.1016/S0167-6296(97)00040-4

Mihaylova, B., Briggs, A., O’Hagan, A., \& Thompson, S. G. (2011). Review of Statistical Methods for Analysing Healthcare Resources and Costs. Health Economics, 20(8), 897-916. https://doi.org/10.1002/hec.1653

Muyl, F., Dumas, L., \& Herbert, V. (2004). Hybrid method for aerodynamic shape optimization in automotive industry. Computers and Fluids, 33(5), 849-858. https://doi.org/https://doi.org/10.1016/j.compfluid.2003.06.007

Ngatchou, P., Zarei, A., \& El-Sharkawi, A. (2005). Pareto Multi Objective Optimization. Proceedings of the 13th International Conference on, Intelligent Systems Application to Power Systems, 84-91. https://doi.org/10.1109/ISAP.2005.1599245

OECD. (2016a). OECD Data Health Expenditure (Percent of GDP). https://doi.org/http://stats.oecd.org/Index.aspx?DataSetCode=SHA

OECD. (2016b). OECD Data Health Expenditure Per Capita. https://doi.org/https://data.oecd.org/healthres/health-spending.htm

OECD. (2017a). Life expectancy at birth 2015. https://doi.org/https://data.oecd.org/healthstat/life-expectancy-at-birth.htm

OECD. (2017b). OECD Data Health Care Resources 2015. https://doi.org/http://stats.oecd.org/Index.aspx?DataSetCode=HEALTH_REAC

OECD. (2017c). Pharmaceutical spending Total, \% of health spending, 2015. https://doi.org/https://data.oecd.org/healthres/pharmaceutical-spending.htm

OECD. (2017d). The Organisation for Economic Co-operation and Development: Members and partners. http://www.oecd.org/about/membersandpartners/\#d. en.194378

OECD. (2017e). World Health Organization's Global Health Workforce Statistics, OECD, supplemented by country data. Physicians (per 1,000 people). https://data.worldbank.org/indicator/SH.MED.PHYS.ZS

Palasca, S., \& Jaba, E. (2015). Economic Crisis' Repercussions on European Healthcare Systems. Procedia Economics and Finance, 23(Supplement C), 525-533. https://doi.org/https://doi.org/10.1016/S2212-5671(15)00568-7

Steiner, M. T. A., Datta, D., Neto, P. J. S., Scarpin, C. T., \& Figueira, J. R. (2015). Multi-objective optimization in partitioning the healthcare system of Parana State in Brazil. Omega, 52(Supplement C), 53-64. https://doi.org/https://doi.org/10.1016/j.omega.2014.10.005

WBG. (2017). The World Bank, GDP Per Capita, (current international \$) 2016. https://doi.org/https://data.worldbank.org/indicator/NY.GDP.PCAP. PP.CD 
